\title{
Adrenal masses in oncology patients
}

\author{
Rodney H Reznek \\ From International Cancer Imaging Society (ICIS) 14th Annual Teaching Course \\ Heidelberg, Germany. 9-11 October 2014
}

In the general population, adrenal masses are demonstrated in 2-9\% of CT scans. Eighty per cent of these are benign cortical adenomas. However, in patients with cancer, over $50 \%$ of detected adrenal masses prove to be metastases. Despite this the techniques for the evaluation of adrenal masses in patients with cancer should be similar to patients without cancer and incidentally discovered adrenal masses. Extensive published material is now available on the diagnostic performance of CT, MRI and PET in the characterization of adrenal masses. It must be borne in mind, however, that these techniques are usually evaluated for their ability to positively identify adenomas. Other adrenal pathology also occurs incidentally and it is essential that the radiologist should be familiar with the range of appearances of this pathology. Examples of this include phaeochromocytomas, cysts, myelolipomas, haemorrhage and granulomatous infections. Furthermore, although cross-sectional imaging techniques, particularly when modified specifically to evaluate indeterminate adrenal masses, can prove to have an excellent diagnostic performance (with remarkably high specificity), all have limitations. It is a consideration of the relative comparative strengths and weaknesses of each of these imaging modalities that informs the choice of technique and interpretation of the findings. This short presentation outlines the key points relating to the most widely used techniques for evaluating the adrenal mass in patients with cancer and the evidence for their role in patient management.

\section{Published: 9 October 2014}

\section{References}

1. Berland $L L$, et al: Managing incidental findings on abdominal CT: White Paper for the Incidental Findings Committee. J Am Coll Radiol 2010, 7(10):754-773.

2. Khoo HJ, et al: The value of 15-minute delayed contrast-enhanced CT to differentiate hyperattenuating adrenal masses compared with chemical shift MRI. Eur Radiol 2014, 24(6):1410-1420.

Correspondence: r.h.reznek@qmul.ac.uk

Imaging Department, St Bartholomew's Hospital, London EC1A 7BE, UK
3. Lee HJ, Lee J: Differential diagnosis of adrenal masses using imaging modality. Special emphasis on F-18 fluoro-2-deoxy2glucose positron emission tomography/ computed tomography. Endocr Metab 2014, 29:5-11.

4. Malayeri $A$, et al: Adrenal masses: contemporary imaging characteristics. JCAT 2013, 37(4):528-542.

5. Mansmann $\mathrm{G}$, et al: The clinically inapparent adrenal masses: update in diagnosis and management. Endocr Rev 2004, 25:309-340.

6. Sahdev A, Reznek R: Adrenal imaging in Grainger \& Allison's Diagnostic Radiology., 6 2015, 1008-1033.

7. Taffel $\mathrm{M}$, et al: Adrenal imaging: a comprehensive review. Radiol Clin $\mathrm{N}$ Am 2012, 50:219-243.

8. Zeiger MA, et al: Medical and surgical evaluation and treatment of incidental adenomas. J Endocrinol Metab 2011, 96(7):2004-215.

doi:10.1186/1470-7330-14-S1-045

Cite this article as: Reznek: Adrenal masses in oncology patients. Cancer Imaging 2014 14(Suppl 1):O45.
Submit your next manuscript to BioMed Central and take full advantage of:

- Convenient online submission

- Thorough peer review

- No space constraints or color figure charges

- Immediate publication on acceptance

- Inclusion in PubMed, CAS, Scopus and Google Scholar

- Research which is freely available for redistribution

Submit your manuscript at www.biomedcentral.com/submit
() Biomed Central
() Biomed Central

C 2014 Reznek; licensee BioMed Central Ltd. This is an Open Access article distributed under the terms of the Creative Commons Attribution License (http://creativecommons.org/licenses/by/4.0), which permits unrestricted use, distribution, and reproduction in any medium, provided the original work is properly cited. The Creative Commons Public Domain Dedication waiver (http:// creativecommons.org/publicdomain/zero/1.0/) applies to the data made available in this article, unless otherwise stated. 